\title{
Utilization of electronic marketing and economic determinants to improve income of dairy cattle farmer in Boyolali, Central Java - Indonesia
}

\author{
A. Setiadi*, S. I. Santoso, M. Mukson, S. Nurfadillah and K. Prayoga \\ Agribusiness Department, Faculty of Animal and Agricultural Sciences, \\ Diponegoro University, Tembalang Campus, Semarang 50275 - Indonesia \\ *Corresponding E-mail: agus_setiadi2006@yahoo.co.id
}

Received March 17, 2020; Accepted May 26, 2020

\begin{abstract}
ABSTRAK
Penelitian ini bertujuan untuk menganalisis dampak pemanfaatan pemasaran elektronik dan mengetahui faktor-faktor penentu ekonomi untuk meningkatkan pendapatan peternak sapi perah di Boyolali, Jawa Tengah Indonesia. Survei dilakukan terhadap 80 peternak sapi perah dari Kecamatan Cepogo, Boyolali yang ditentukan dengan simple random sampling. Hasil penelitian menunjukkan ratarata produksi susu adalah 8,3 liter/ekor/hari, penerimaan sebesar Rp 4.414 .000 per bulan, biaya produksi Rp 2.105.000 per bulan, dan pendapatan sebesar Rp 2.309.000 per bulan. Selanjutnya dengan memanfaatkan elektronik, peternak dapat menjual $40 \%$ produknya ke kedai kopi dan menghasilkan

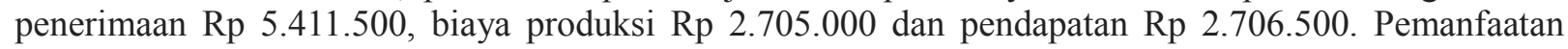
pemasaran elektronik dapat meningkatkan R/C dari 2,1 menjadi 2,43. Faktor-faktor ekonomi yang mempengaruhi pendapatan adalah harga pasar, biaya transportasi dan komunikasi, biaya pemasaran dan jarak tempuh. Berdasarkan hasil penelitian dapat disimpulkan bahwa pemanfaatan pasar elektronik dapat memperluas pasar, meningkatkan harga susu dan akhirnya akan meningkatkan pendapatan.
\end{abstract}

Kata kunci : faktor ekonomi, pendapatan, pemasaran elektronik, sapi perah, susu

\begin{abstract}
This study aimed to analyze the impact of electronic marketing utilization and to determine the economic determinants to increase the income of small dairy farmers in Boyolali, Central Java, Indonesia. A survey of 80 dairy farmers from the Cepogo District, Boyolali was determined by simple random sampling. The results showed that the average milk production was 8.3 liters/head/day, the revenue of IDR 3,824,000 per month, production costs of IDR 2,105,000 per month, and income of IDR $1,719,000$ per month. Furthermore, by using electronics marketing, farmers could sell $40 \%$ of their products to coffee shops and generate revenue of IDR 5,411,500, production costs of IDR 2,705,000 and income of IDR 2,706,500. The utilization of the electronic marketing could increase R/C from 2.1 to 2.43. Economic factors that influence income are market prices, transportation and communication costs, marketing costs and distance traveled. Based on the results of the study it can be concluded that the use of the electronic market can expand the market, increase milk prices and ultimately will increase income
\end{abstract}

Keywords: dairy cattle, economic factors, electronic marketing, income, milk 


\section{INTRODUCTION}

Milk is one of the important livestock commodities in Indonesia. Because of the milk demand is greater than its supply, the Indonesian government still import milk from other countries such as from New Zealand and Australia. In Indonesia, the purpose of dairy cattle raised to produce fresh milk. Setianti et al. (2017) stated dairy cattle in Indonesia only produce fresh milk less than 10 liters/heads/day. Further, Setianti et al. stated milk production was influenced by number lactation cow, quality and quantity of milk, and price decided by cooperative and milk processing industry. While the problems faced by dairy cattle farmers in Boyolali are lack of market accessibility and low milk quality.

The milk processing industry has a dominant position to decide the milk market price. In Boyolali, the dairy cattle business is done by farmers to add their income besides the main business as a crop farmer. Dairy cattle farmers sell milk through direct marketing. Dairy cattle farmers usually sell fresh milk to the cooperative around their area. Dairy cattle farmers have not utilized yet the electronic market. Utilization technology could increase marketing effectiveness (Bahera et al., 2015). The research focused on dairy cattle income in Indonesia was done by some researchers (Dolewikou et al., 2016; Setianti et al., 2017; Haloho et al., 2013).

Setianti et al. (2017) stated that dairy cattle farms have an advantage for a farmer to give additional income besides the income from a crop farmer. In Central Java, usually, dairy cattle farmers raise 2-3 heads of dairy cattle. Farmer raise dairy cattle use traditional technology, so milk production is low and the milk quality is poor. They sell fresh milk to the cooperative at a low price. The utilization of electronic marketing will able to increase income because farmers can access other markets that have higher price (Baumuller, 2018; Gillespie et al., 2007; Larsen and Gilliand, 2009).

Utlization of industry 4.0 to market milk is needed. Some researches were done using industry 4.0 on agricultural sector (Depeyrot and Duval (2018); Larsen and Gilliland (2009); Koirala et al. (2019); Roy et al. (2019) and Ordolff (2001)). Khana et al. (2019) stated utilization technology could improve food processing. Studman (2001) stated the internet can be used in many things, such as marketing. Rupnik et al. (2019) stated industry 4.0 could be applied to agricultural activity. Kim et al. (2019) stated industry 4.0 was applied in mastitis detection. Improving marketing technology can improve the market price. Application of industry 4.0 in innovation technology would improve business efficiency (Annosi et al. (2019), Lezoche et al. (2020) and Frank et al. (2019)). Industry 4.0 could solve the production, innovation, financial and marketing as well (Lezoche et al., 2020) Electronic marketing using internet was done by some researchers (Mathews et al. (2015), and M'kwiriga and Imaita (2018)). Further M'kwiriga and Imaita (2018). stated utilization electronic marketing would increase market price and improve market efficiency.

Up to present many coffee shop growths in Boyolali Regency follow the lifestyle of young generation. The electronic market is still not utilized yet by the farmer. Almost all dairy cattle farmers in Boyolali still utilized traditional marketing strategy, dairy cattle farmer still not used yet internet, WhatsApp, etc to market their fresh market, so the research which investigated the scenario of utilization electronic marketing to increase their income is needed. The objectives of the study were to analyze the impact of electronic marketing utilization and to determine the economic determinants to increase the income of small dairy farmers in Boyolali, Central Java, Indonesia.

\section{MATERIALS AND METHODS}

The survey method was used in the study. Eighty (80) dairy farmers were chosen as the respondent by simple random sampling. The study was conducted in Cepogo District, Boyolali. The district was chosen because this district has the highest milk production $(9,565,219$ liters/year) in Boyolali Regency compared to other districts. The primary data was collected through direct interviews with the farmer and data were observed in the field. Revenue, cost of production and income were computed in this study. The feasibility was projected if the electronic marketing is applied. If farmers use electronic marketing, they can sell $40 \%$ of their products to coffee shops and $60 \%$ of products will be sold to cooperative. The coffee shop would order fresh milk using electronic devices like cellular phone and the farmer would deliver the milk. When the farmer sold fresh milk to the cooperative they got IDR 5,000/liter but if they sell the fresh milk to the coffee shop in Boyolali district they will get 
IDR 8,000/liter. Income was calculated based on the formula of Septiani et al. (2017):

$$
\begin{aligned}
& \mathrm{TR}=\mathrm{Py} \times \mathrm{Y} \\
& \mathrm{TC}=\mathrm{TFC}+\mathrm{TVC} \\
& \pi \quad \mathrm{TR}-\mathrm{TC}
\end{aligned}
$$

where TR is the total of dairy farmer revenue (IDR/month), TC is the cost total of dairy farmer (IDR/month), $\pi$ is income (IDR/month), TFC is total fixed cost (IDR/month), Py is the output price (IDR/month), Y is the total of the output (liter/month) and TVC is the total of variable cost (IDR/month)

\section{Return/Cost Ratio}

Return cost ( $\mathrm{R} / \mathrm{C}$ ratio) was calculated based on the formula of Septiani et al. (2017):

$\mathrm{R} / \mathrm{C}$ on total cost $=($ Total revenue $) /($ Total Cost $)=$ $\mathrm{TR} /(\mathrm{TC})$

Assessment criteria were:

a. If the value of $\mathrm{R} / \mathrm{C}$ ratio $>1$ then, dairy cattle business is feasible.

b. If the value of $\mathrm{R} / \mathrm{C}$ ratio $<1$ then the dairy cattle business is not feasible.

c. If the $\mathrm{R} / \mathrm{C}$ ratio $=1$ then the farm is said to break even point (BEP)

Regression analysis was determine to effect of economic factor on dairy cattle farmer income. $\mathrm{Y}=\mathrm{a}+\mathrm{b} 1 \mathrm{X} 1+\mathrm{b} 2 \mathrm{X} 2+\mathrm{b} 3 \mathrm{X} 3+\mathrm{b} 4 \mathrm{X} 4+\mathrm{e}$ where $\mathrm{Y}=$ Income (IDR/month), $\mathrm{a}=$ constant, $\mathrm{b} 1$, b2, b3, b4 = regression coefficients, $\mathrm{X} 1=$ market price (IDR/liter), $\mathrm{X} 2=$ transportation and communication cost (IDR/month), X3 = labor cost $(\mathrm{IDR} / \mathrm{month}), \mathrm{X} 4=$ market distance $(\mathrm{km})$, and $\mathrm{e}=$ error

\section{RESULTS AND DISCUSSION}

\section{Characteristic of Dairy Cattle Farmers}

The age of respondents (40-50 years) was $20 \%$, respondents age 50-60 years were $80 \%$. The young generation less interested to do dairy cattle business, because of low income was obtained. The lactation cow owned by them is 3 heads on average. The milk production was 8,3 liters/cow/day. Up to present all of farmers still sold fresh milk to the Cepogo cooperative (Table 1). The milk price was IDR 5,000 per liters but if the coffee shop bought fresh milk, they paid IDR 8,000 per liter. Some coffee shop is developed in Boyolali urban area, this coffee shop needs milk supply from the dairy cattle farmer. The distance between dairy cattle center and Boyolali urban was around $15 \mathrm{~km}$. Dairy farmers still market
Table 1. Socio Economic Characteristics

\begin{tabular}{lc}
\hline \multicolumn{1}{c}{ Respondent characteristic } & Number \\
\hline Age (year) & 54 \\
Educational Background (\%) & \\
$\quad$ Junior high School & 10 \\
$\quad$ Senior High School & 90 \\
Experiences (year) & 15 \\
Scale of ownership (heads) & 3 \\
Milk Production (liters/cow/day) & 8.3 \\
Marketing system & Traditional \\
\hline
\end{tabular}

fresh milk traditionally, they brought to the cooperative.

\section{Cost of Production}

Variable cost consists of feed concentrate cost, artificial insemination cost, vitamin cost, grass feed cost, and labor cost Feed concentrate cost was the highest number (34.44\%) as shown in Table 2. Labor cost was computed as $28.50 \%$ of the total production cost. The farmers usually fed concentrate feed to cattle every day. The concentrate of feed related with milk production. Nutrient availability tends to produce good milk in quantity as well as quality. In agreement with Septiani et al. (2017) feed cost was the highest cost in the dairy cattle business. Efforts to looking for low-cost feed were needed to decrease the production cost.

\section{Revenue}

It can be seen in Table 3, revenue comes from selling milk, selling young dairy cattle and the gain of cattle. Revenue from selling milk per month was IDR 2,490,000, revenue from selling calf was IDR 950,000 per head and the gain of cattle was IDR 974,000. The revenue of dairy cattle farmers in Boyolali is greater than revenue dairy cattle farmers in Semarang Regency which reported by Dolewikou et al. (2016). The revenue of dairy cattle farmers in Semarang Regency was just only IDR 4,414,000 per month. The revenue was greater in Boyolali because the milk market price in Boyolali was higher than in Semarang Regency. Manure not utilized yet as revenue, usually farmer use this for land fertilizer. 
Table 2. Average Cost of Production Per Month

\begin{tabular}{clrr}
\hline No & \multicolumn{1}{c}{ Kind of Cost } & Cost (IDR) & Percentage (\%) \\
\hline 1 & Variable cost & & \\
& Concentrate feed cost & 725,000 & 34.44 \\
& Artificial Insemination cost & 62,000 & 2.95 \\
& Vitamin cost & 30,000 & 1.43 \\
& Grass Feed Cost & 200,000 & 9.50 \\
& Labor Cost & 600,000 & 28.50 \\
2 & Fixed Cost & & 14.25 \\
& Cattle Depreciation & 300,000 & 8.46 \\
& Barn Depreciation & 178,000 & 0.48 \\
& Facility Depreciation & 10,000 & 100.00 \\
\hline & Cost of Production Total & $2,105,000$ & \\
\hline
\end{tabular}

Table 3. Average of Revenue Per Month

\begin{tabular}{clc}
\hline No & Kind of Revenue & Number (IDR) \\
\hline 1 & Milk sold & $2,490,000$ \\
2 & Calf Sold & 950,000 \\
3 & Gain of Cattle & 974,000 \\
& Total of Revenue & $4,414,000$ \\
\hline
\end{tabular}

Table 4. Average of Income per Month

\begin{tabular}{clc}
\hline No & \multicolumn{1}{c}{ Item } & Number (IDR) \\
\hline 1 & Revenue & $4,414,000$ \\
2 & Production Cost & $2,105,000$ \\
3 & Income & $2,309,000$ \\
& R/C & 2.10 \\
\hline
\end{tabular}

\section{Income}

As shown in Table 4 dairy cattle income per month was 2,309,000 and the $\mathrm{R} / \mathrm{C}$ ratio was 2.1. This $\mathrm{R} / \mathrm{C}$ ratio was feasible because it was greater than 1 . The $\mathrm{R} / \mathrm{C}$ ratio 2.1 indicated that every cost spent IDR 1,000 could accept revenue IDR 2,100. The increasing number of $\mathrm{R} / \mathrm{C}$ would indicate the farm more efficient. The income mostly comes from milk sold. The increasing number of milk sold would increase the revenue and finally would increase the income.

\section{Utilization of Electronic Marketing}

Industry 4.0 was the best strategy to solve the marketing problem in the dairy business. Dairy cattle farmers through farmers group using electronic market, they would spend for additional cost, communication and transportation cost. They used WhatsApp and Facebook to market the product. Farmers sold $60 \%$ product to cooperative and $40 \%$ of product was sold to coffee shop using electronic market so they spent IDR 400,000 for communication and transportation cost and the marketing cost was IDR 200,000 , so the total number of production cost was IDR 2,705,000.

The production cost if dairy cattle farmers using electronic marketing would increase (Table 5). There are additional transportation and communication cost and marketing cost but the milk market price also increased. Transportation and communication cost would occur to buy gasoline and quota cellphone. Marketing costs would occur to promote milk prices like produced leaflet, etc.

\section{Revenue}

Dairy cattle farmers accepted revenue was IDR $6,555,400$, the revenue comes from milk sold, young dairy cattle sold and value-added 
Table 5. Average Cost of Production Per Month After Utilized Electronic Market

\begin{tabular}{clrc}
\hline No & \multicolumn{1}{c}{ Kind of Cost } & Number (IDR) & Percentage (\%) \\
\hline 1 & Variable Cost & & \\
& Feed Concentrate cost & 725,000 & 26.80 \\
& Artificial Insemination cost & 62,000 & 2.29 \\
& Vitamin cost & 30,000 & 1.11 \\
& Grass Feed Cost & 200,000 & 7.39 \\
& Labor Cost & 600,000 & 22.18 \\
Communication and Transportation cost & 400,000 & 14.79 \\
Marketing cost & 200,000 & \\
Fix Cost & & 11.09 \\
Cattle Depreciation & 300,000 & 6.58 \\
Barn Depreciation & 178,000 & 0.37 \\
Facility Depreciation & 10,000 & 100.00 \\
\hline
\end{tabular}

Table 6. Average of Revenue Per Month After Utilized Electronic Market

\begin{tabular}{clr}
\hline No & Kind of Revenue & Number (IDR) \\
\hline 1 & Milk sold & $4,631,400$ \\
2 & Calf sold & 950,000 \\
3 & Value added of Cattle & 974,000 \\
& Total of Revenue & $6,555,400$ \\
\hline
\end{tabular}

Table 7. Average of Income Per Month After Utilized Electronic Market

\begin{tabular}{clc}
\hline No & \multicolumn{1}{c}{ Item } & Number (IDR) \\
\hline 1 & Revenue & $5,411,500$ \\
2 & Production Cost & $2,705,000$ \\
3 & Income & $3,850,400$ \\
& R/C ratio & 2.3 \\
\hline
\end{tabular}

cattle (Table 6). The increasing market price when the farmers applied the electronic market. The increasing market price when utilized electronic market. The market price was IDR 8,000 when using electronic market scenario. This market price would increase revenue. The price would high than the price in dairy cooperative because the coffee shop was the direct consumer. This result in agreement with Annosi et al. (2018) and Khana et al. (2019) which stated utilization industry 4.0 on marketing strategy would increase the revenue. Utilization of industry 4.0 would trigger the farmer to always maintain the quality of the product.

\section{Income}

Income dairy cattle farmer was $3,850,400$ and $\mathrm{R} / \mathrm{C}$ was 2.4. Irissaria et al. (2019) stated the application of industry 4.0 in beef production increased the income (Table 7). The utilization of industry 4.0 tends to improve the milk market sold. The $\mathrm{R} / \mathrm{C}$ ratio increased when the electronic market applied. The study in agreement with Hemme et al. (2014), which stated increasing market price would increase the income. The increasing number of $\mathrm{R} / \mathrm{C}$ ratio showed the scenario using electronic marketing more 
Table 8. Economic Determinants of Utilization Electronic Market

\begin{tabular}{clccc}
\hline No & \multicolumn{1}{c}{ Items } & Coefficients & SE & P Values \\
\hline 1 & Constant & -7880.5 & 0.45 & 0.003 \\
2 & Market price & 345 & 0.98 & 0.002 \\
3 & Transportation and & 300 & 0.23 & 0.004 \\
& communication cost & & & \\
4 & Marketing cost & 450 & 0.46 & 0.004 \\
5 & Market distance & -500 & 0.06 & 0.000 \\
\hline
\end{tabular}

effectively. This result in agreement with Koirala et al. (2019) utilization of computers on agriculture would increase the farmer income, utilization of industry 4.0 would produce effective cost and finally would increase the income.

\section{Economic Determinants}

As shown in Table 8, using regression analysis to determine economic factors that influenced the income after utilized electronic marketing. Market price, transportation and communication cost, labor cost and market distance influenced the income significantly $(\mathrm{P}<0.05)$. Increasing market price would improve the income when farmer applied electronic marketing. The application of electronic marketing would increase transportation and communication cost and labor cost. Increasing market distance would decrease the income, the furthest market distance from the farmer location was $15 \mathrm{~km}$. Economic determinant showed to keep the market price still high, dairy cattle farmer should maintain the milk quality. Setianti et al. (2017) stated milk quality was an important factor that influenced the market price. This result in agreement with Mathews et al. (2016) that stated increasing market price tends to increase the income. Increasing market price also triggered producers to supply more number of the product to the market.

\section{CONCLUSION}

Utilization industry 4.0 in dairy cattle business would solve the marketing problem of dairy cattle farmer. Utilization of electronic market leads to increasing the income from IDR $2,309,000$ to IDR $3,850,400$. $\mathrm{R} / \mathrm{C}$ ratio was increased from 2.1 to 2.4 . Scenario using the electronic market would increase the production cost. The revenue would increase because using this scenario would increase the milk market price from IDR 5,000 to IDR 8,000. Utilization of electronic market would efficiently increase the income. The factors influencing the income were market price, transportation and communication cost, labor cost and market distance.

\section{REFERENCES}

Annosi, M.C., F. Brunetta., A. Monti and F. Nati. 2018. Is the trend your friend? An analysis of technology 4.0 investment decision in agricultural SMEs. Computers in Industry. 109(4): 59-71.

Baumuller, H. 2017. The little we know: an explanatory literature review on the utility of moble phone-enabled services for smallholder farmers. J. Int. Dev. 30(1): 134-154.

Depeyrot, J.N. and M. Duval. 2018. Global dairy trade, an electronic marketing platform from New Zealand: What opportunities for global dairy markets? Economie Rurale. 2(364): 31-54.

Dolewikou, R.L., W. Sumekar and A. Setiadi.2016. The profitability analysis of dairy cattle business on the group of dairy farmers in West Ungaran District, Semarang Regency. J. Indonesian Trop. Anim. Agric. 41(4): 216-223.

Frank, A.G., L.S. Dalenogare and N.F. Ayala. 2019. Industry 4.0 technologies: Implementation patterns in manufacturing companies. Int. J. Prod. Econ. 210(1):1526.

Gillespie, G., D.L. Hilchey, C.C. Hinrichs and G. Feenstra. 2007. Farmers' markets as 
keystones in rebuilding local and regional food systems. Remarking the North American Food System: Strategies for Sustainability, University of Nebraska Press, Lincoln pp. 65-83.

Haloho, R.D., S.I. Santoso, S. Marzuki, W. Roessali and A. Setiadi. 2013. Profit function analysis of dairy cattle farming in Getasan and west Ungaran Districts, Semarang Regency. J. Indonesian Trop. Anim. Agric. 38(2): 116-122.

Hemme, T., M.M. Uddin and O.A. Ndambi. 2014. Benchmarking cost of milk production in 46 countries. J. Rev. Global Econ. 3(2): 254-270.

Irisarria, J.G., J.D. Dernerb, J. P. Rittenc and D. E. Peck. 2019. Beef production and net revenue variability from grazing systems on semiarid grasslands of North America. Livest. Sci. 220(2): 93-99.

Khana, Z.K., A. Khalidb and J. Iqbal. 2019. Towards realizing robotic potential in future intelligent food manufacturing system. Innovative Food Science and Emerging Technologies 48 (4): 11-24.

Kim, H., Y. Min and B. Choi. 2019. Real-time temperature monitoring for the early detection of mastitis in dairy cattle: Methods and case researches. Computers Elect. Agric. 169(4): 122-130.

Koirala, A., K.B. Walsha., Z.Wanga and C. McCarth. 2019. Deep learning-Method overview andre view of use for fruit detection and yield estimation. Computers Elect. Agric. 162(8): 219-234.

Larsen, K and J. Gilliland. 2009. A farmers' market in food desert: Evaluating impacts on the price and availability of healthy food. Health Place. 4(9): 1158-1162.
Lezoche, M., J.E. Hernandez and M.M. E.A. Diaz. 2020. Agri-food 4.0: A survey of the supply chains and technologies for the future agriculture. Computers in Industry 117(10): 1-14.

Mathews, S., C. Bianchi., K. J. Perks., M. Healy and R. Wickramasekera. 2016. Internet marketing capabilities and international market growth. Int. Business Review. 25(4): $820-830$

M'kwiriga, M.G. and I. Imaita. 2018. Factors influencing adoption of e-marketing on dairy products in Meru: a cas of Meru dairy cooperative union, Kenya. Int. Academic J. Human Res. Business Administration. 3(3): 100-119.

Ordolff. 2001. Introduction of electonics into milking technology. Computer and Electronics in Agriculture 30(3): 125-149.

Roy, P., A. K. Islaya., P. A. Plonskia and J. L. V. Isler. 2019. Vision- based preharvest yield mapping for apple orchards. Computers Elect. Agric. 18(8): 36-43.

Rupnik, R., M. Kukar, P. Vračar, D. Košir, D. Pevec and Z. Bosnić. 2019. AgroDSS: A decision support system for agriculture and farming. Computers Elect. Agric. 161(9): 260-271.

Septiani, W., Marimin, Y. Herdiyeni and L. Haditjaroko. 2017. Risk based milk pricing model at dairy farmers level. Media Peternakan 40(3): 218-227.

Setianti, C., T. Ekowati and A. Setiadi. 2017. Market integration of fresh milk in dairy business area of Pamijahan District and Cisarua District, Bogor Regency-Indonesia. J. Indonesian Trop. Anim. Agric. 42(1):4247. 